\title{
Latitudinal comparisons of reproductive traits in five Brachyuran species along the Chilean coast
}

\author{
Comparaciones latitudinales de aspectos reproductivos en cinco especies \\ de braquiuros a lo largo de la costa de Chile
}

\begin{abstract}
ANTONIO BRANTE ${ }^{1}$, SANDRA CIFUENTES ${ }^{1}$, HANS-OTTO PÖRTNER ${ }^{2}$,
\end{abstract} WOLF ARNTZ² \& MIRIAM FERNÁNDEZ ${ }^{1, *}$

\begin{abstract}
${ }^{1}$ Estación Costera de Investigaciones Marinas and Center for Advanced Studies in Ecology \& Biodiversity, Departamento de Ecología, Facultad de Ciencias Biológicas, Pontificia Universidad Católica de Chile, Casilla 114-D, Santiago, Chile

${ }^{2}$ Alfred-Wegener-Institut, Columbusstrassen, D-27568 Bremerhaven, Germany

*Corresponding author: mfernand@genes.bio.puc.cl
\end{abstract}

\begin{abstract}
Understanding large-scale patterns in reproductive investment and fecundity of marine invertebrates is important for determining the critical environmental variables affecting reproduction and thus, the spatial patterns of population dynamics. However, information on patterns of reproduction of marine invertebrates at large spatial scales are either scarce, or have been conducted by mixing species with contrasting modes of development. Brachyuran crabs are an ideal group to analyze large-scale patterns of reproduction not only because many species are commercially exploited, but also because they show a single mode of larval development and wide distributional ranges. Here, we report latitudinal patterns of reproductive variables in

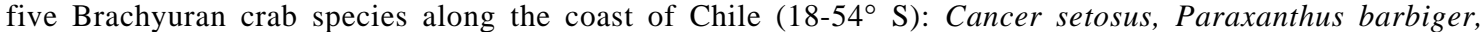
Homalaspis plana, Ovalipes trimaculatus, and Taliepus marginatus. Five variables were analyzed: brood weight, fecundity, embryo dry weight, embryo volume, and embryo loss. Comparisons between northern $\left(20^{\circ}\right.$ S), central $\left(29-33^{\circ} \mathrm{S}\right)$ and southern Chile $\left(35-41^{\circ} \mathrm{S}\right)$ were conducted for $C$. setosus and between central and southern Chile for the other four species. A total of 378 brooding females were collected and analyzed. Although we did not find a clear and consistent pattern in all reproductive variables in the five crab species analyzed along the coast of Chile, generalizations can be drawn from this study. First, brood weight did not vary between central and southern Chile in most of the species (except $P$. barbiger). Second, embryo loss did not vary between central and southern Chile in four of the species studied. Third, embryo dry weight tended to increase toward high latitudes in four of the five species. We suggest that the costs associated to oxygen provision to broods may explain some of the patterns found, but other factors need also be considered.
\end{abstract}

Key words: reproductive investment, fecundity, brooding, crabs, embryo loss.

\section{RESUMEN}

El estudio de los patrones de inversión reproductiva y fecundidad en invertebrados marinos a escalas espaciales grandes es de vital importancia para determinar las variables ambientales críticas que afectan la reproducción, y así poder entender los patrones espaciales de las dinámicas poblacionales. Sin embargo, la información sobre patrones de reproducción en invertebrados marinos a gran escala es escasa, y en algunos casos ha sido generada tomando en cuenta especies con diferentes modos de desarrollo. Los crustáceos braquiuros son un grupo de gran interés para analizar patrones de reproducción a gran escala no solo por la importancia comercial de muchas especies sino también por presentar un único modo de desarrollo larval y un amplio rango de distribución geográfica. En este trabajo reportamos los patrones reproductivos de cinco especies de braquiuros: Cancer setosus, Paraxanthus barbiger, Homalaspis plana, Ovalipes trimaculatus y Taliepus marginatus, a lo largo de la costa de Chile $\left(18-54^{\circ} \mathrm{S}\right)$. Cinco variables fueron analizadas: peso de la masa de embriones, fecundidad, peso seco del embrión, volumen del embrión y pérdida de embriones. Se realizaron comparaciones entre el norte $\left(20^{\circ} \mathrm{S}\right)$, centro $\left(29-33^{\circ} \mathrm{S}\right)$ y sur de Chile $\left(35-41^{\circ} \mathrm{S}\right)$ para C. setosus, y entre el centro y sur de Chile para las otras cuatro especies. Se recolectaron y analizaron un total de 378 hembras ovígeras. Aunque no detectamos un patrón bien definido para todas las variables reproductivas en las especies analizadas a lo largo de la costa de Chile, emergieron al menos tres generalidades. Primero, en la mayoría de las especies el peso de la masa de embriones no varió entre el centro y sur de Chile (exceptuando $P$. barbiger). Segundo, la pérdida de embriones no varió entre el centro y sur de Chile en cuatro de las especies estudiadas. Tercero, el peso seco del embrión tendió a aumentar en poblaciones de latitudes altas en cuatro de las especies analizadas. Proponemos que el costo asociado a la provisión de oxígeno a los embriones puede explicar alguno de los patrones encontrados, aunque otros factores necesitan ser considerados.

Palabras clave: inversión reproductiva, fecundidad, incubación, jaibas, pérdida de embriones. 


\section{INTRODUCTION}

The understanding of large-scale patterns of reproductive investment and fecundity of marine invertebrates is of importance for several reasons. First, analysis over large spatial scales could help in the identification of potential links between egg production and environmental variables. Second, spatial patterns of reproduction could also help to improve our understanding of spatial patterns of population dynamics, information that could be critical for management of open populations under exploitation. Finally, large-scale analyses of investment in reproduction could also shed lights on our understanding of key aspects shaping life history patterns of marine invertebrates, including large-scale patterns of distribution of modes of development (latitude and depth; Thorson 1950 but see also Spight 1977, Gallardo \& Penchaszadeh 2001), and help explain the distribution of species in the oceans. At present, information on patterns of reproduction of marine invertebrates at largescales are either scarce, or have been conducted by mixing species with contrasting modes of development (e.g., Clarke 1987, Brey 1995).

Studies of reproductive patterns along the coast of Chile offer the opportunity to analyze an extended latitudinal range, with mean temperatures ranging from 6 to $20{ }^{\circ} \mathrm{C}$, contrasting upwelling regimes that affect the oxygen minimum zone (Strub et al. 1998), and dramatic differences in circulation patterns (from northern Chile to the fjords area, Strub et al. 1998). It is unclear if the patterns of investment in reproduction of marine invertebrates respond to the monotic changes of critical environmental variables, such as temperature (Clarke 1987, Brey 1995), or show rather abrupt changes in areas where other environmental variables vary (e.g., oxygen availability for brooding species: Cohen \& Strathmann 1996; circulation patterns: Giraldo et al. 2002). Brachyuran crabs are an ideal group of organisms to analyze large-scale patterns of reproduction not only because many species are commercially exploited, but also because they show a single mode of larval development and wide distributional ranges (Boschi 2000). Sea surface temperature shows a clear gradient along the coast of Chile and has been shown to affect several interdependent reproductive variables of Brachyuran crabs (Brante et al. 2003). Temperature affects embryo oxygen consumption, producing changes in patterns of embryo ventilation by females (Fernández et al. 2002), which affects investment in brood care, reproductive output, and embryo loss (Brante et al. 2003). Thus, embryo loss during incubation along a latitudinal gradient could be an important variable to be included in the evaluation of the cost of reproduction in Brachyuran crabs (Kuris 1991, Fariña et al. 1999, Lardies \& Castilla 2001). Latitudinal trends in oxygen concentration in the water column may also be critical in explaining largescale patterns of reproduction in the ocean given the link between brooding and oxygen provision to the brood (Fernández et al. 2000, Baeza \& Fernández 2002). Large-scale patterns of reproductive variables of interest, such as brood weight, fecundity, embryo loss, and egg size are yet unclear (see Jones \& Simons 1983, Carvacho et al. 1995, Lardies \& Castilla 2001, Brante et al. 2003), as are the relationships between these patterns and environmental variables.

Herein we report latitudinal patterns of reproductive variables in five Brachyuran crab species along the coast of Chile: Cancer setosus, Paraxanthus barbiger, Homalaspis plana, Ovalipes trimaculatus and Taliepus marginatus. Five variables were analyzed: brood weight, fecundity, embryo dry weight, embryo volume, and embryo loss. Comparisons between northern $\left(20^{\circ} \mathrm{S}\right)$, central $\left(29-33^{\circ} \mathrm{S}\right)$ and southern Chile $\left(35-41^{\circ} \mathrm{S}\right)$ were conducted for $C$. setosus and between central and southern Chile for the other four species. Morphometric and reproductive relationships were established for each species in each region. The presence of a single mode of larval development among Brachyuran crabs is a characteristic of major importance considering that investment in brood care can be substantial and may affect the comparisons of other reproductive variables.

\section{MATERIAL AND METHODS}

In order to explore latitudinal trends in some reproductive variables of Brachyuran crabs along the Chilean coast, ovigerous females of the following five species were collected: Cancer setosus, Paraxanthus barbiger, Homalaspis plana, Ovalipes trimaculatus and Taliepus marginatus. Three regions of Chile were compared (named here north, center and south) and between two and three sites were sampled within each region. The sites sampled in the north were located near Iquique $\left(20^{\circ} 14\right.$ ' $\left.\mathrm{S}, 70^{\circ} 10^{\prime} \mathrm{W}\right)$. The sites sampled in the center were located between Coquimbo (29 $58^{\circ} \mathrm{S}$, $71^{\circ} 22^{\prime} \mathrm{W}$ ) and San Antonio (33 $36^{\circ} \mathrm{S}, 71^{\circ} 38^{\prime}$ W) and those in the south between Curanipe

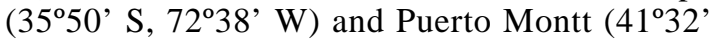


S, $72^{\circ} 59^{\prime}$ W; Fig. 1). Females of C. setosus were collected in shallow waters in the three regions (latitudinal range: 21 degrees). Mean annual sea-surface temperature was $18{ }^{\circ} \mathrm{C}$ in north, $14^{\circ} \mathrm{C}$ in center, and $10^{\circ} \mathrm{C}$ in south Chile. These temperatures were calculated using information from the last 10 years (Servicio Hidrográfico y Oceanográfico de la Armada de Chile 1996). Unfortunately, we could not find ovigerous females of $P$. barbiger, $H$. plana, $O$. trimaculatus and $T$. marginatus in northern Chile, despite that several trips to the north were conducted (and only one or two to the other sites). Thus, data for these species are available only for the central and southern Chile (12 degrees). The collection sites of south Chile were located in the southern limit of the distribution of $P$. barbiger and $T$. marginatus (Fig. 1). Between 11 and 35 crabs incubating early stage embryo masses and between five and 47 females carrying late stage embryo masses of each species were analyzed for each region (Table 1). Samples were collected by local fishermen between February 1999 and December 2000 (several visits to each sampling site), frozen immediately, and shipped to the Estación Costera de Investigaciones Marinas at Las Cruces where the samples were processed. Each brooding female was categorized according to the developmental stage of the embryos. The following developmental stage categories were used: (1) early (from embryos exhibiting uniformly distributed yolk, absence of cleavage and eyes, to embryos with cleavage and yolk reduced to not less than $75 \%$ of embryo volume; see Fernández et al. 2002), and (2) late (from embryos displaying pigments and visible but undeveloped eyes, to embryos with well developed eyes, heart, and appendages). In order to exclude erroneous
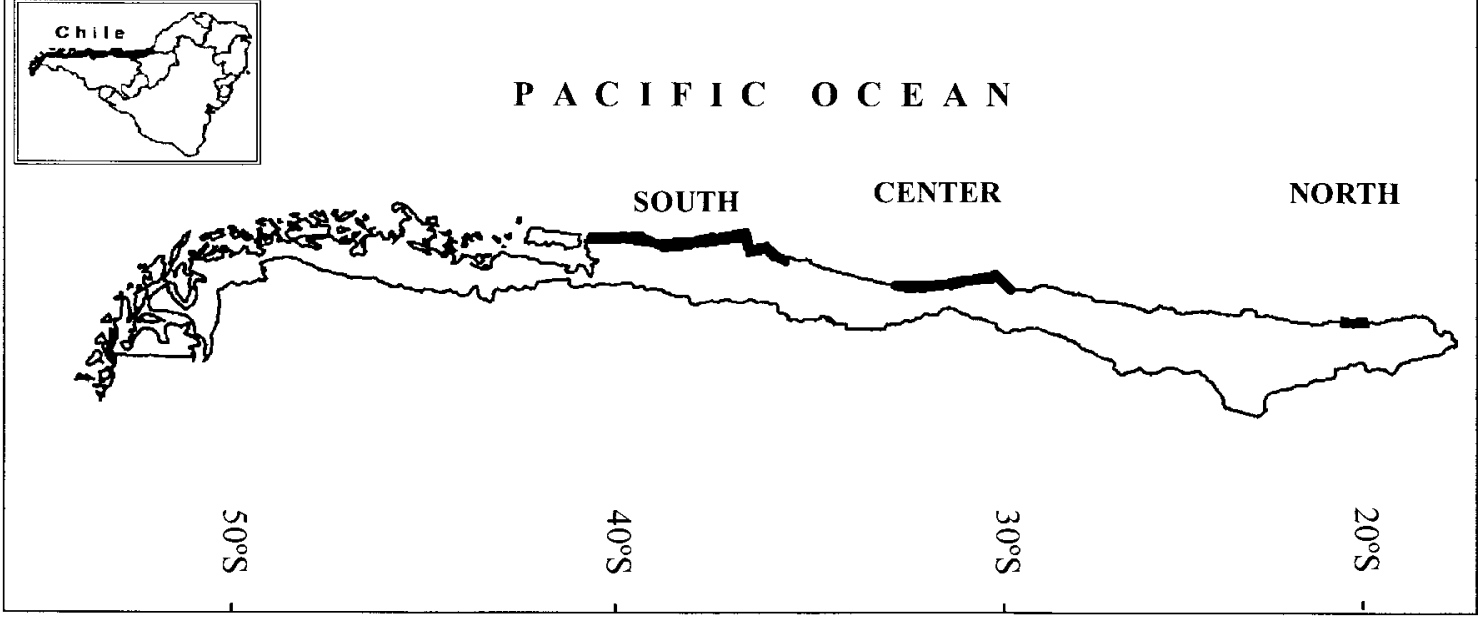

Fig. 1: Map of Chile showing the sampling regions (north, center and south). Horizontal, solid bars show the distributional ranges reported in the literature for each species. Extensions in reported ranges of distribution based on this study are shown with open bars.

Mapa de Chile que muestra las regiones analizadas (norte, centro y sur). Las barras horizontales obscuras muestran el rango de distribución reportado en la literatura para cada especie. Las barras verticales blancas muestran extensiones en el rango de distribución basadas en este estudio. 
TABLE 1

Number (n) of females sampled at each region for the five species analyzed.

Mean carapace wide (CW), female dry weight (FDW) and dry weight of embryo mass (BDW) are also reported. Standard errors are shown in parentheses

Número $(\mathrm{N})$ de hembras analizadas en cada región para las cinco especies estudiadas. Se muestra el ancho medio de caparazón (CW), peso seco de la hembra (FDW) y peso seco de la masa de embriones (BDW). Entre paréntesis se muestran los errores estándar

\begin{tabular}{|c|c|c|c|c|c|c|c|c|c|}
\hline \multirow{3}{*}{$\begin{array}{l}\text { Species } \\
\text { Cancer setosus }\end{array}$} & \multirow{3}{*}{$\begin{array}{l}\text { Region } \\
\text { North }\end{array}$} & \multicolumn{2}{|c|}{$\mathrm{n}$} & \multirow{2}{*}{\multicolumn{2}{|c|}{$\mathrm{CW}(\mathrm{cm})$}} & \multirow{2}{*}{\multicolumn{2}{|c|}{ FDW (g) }} & \multirow{2}{*}{\multicolumn{2}{|c|}{ BDW (g) }} \\
\hline & & \multirow{2}{*}{$\begin{array}{c}\text { Early } \\
35\end{array}$} & \multirow{2}{*}{$\begin{array}{r}\text { Late } \\
40\end{array}$} & & & & & & \\
\hline & & & & 100.3 & $(2.1)$ & 74.7 & $(4.8)$ & 9.7 & $(0.4)$ \\
\hline & Center & 25 & 47 & 93.3 & $(2.0)$ & 53.1 & $(3.3)$ & 10.4 & $(0.8)$ \\
\hline & South & 34 & 18 & 101.1 & $(2.9)$ & 85.7 & $(7.9)$ & 15.5 & (1.4) \\
\hline Paraxanthus barbiger & Center & 14 & 7 & 44.1 & $(2.5)$ & 8.9 & $(1.3)$ & 0.7 & $(0.1)$ \\
\hline & South & 30 & 8 & 52.9 & $(1.3)$ & 15.4 & $(1.0)$ & 1.6 & $(0.1)$ \\
\hline Homalaspis plana & Center & 24 & 28 & 99.6 & $(2.7)$ & 97.1 & $(8.8)$ & 10 & $(0.8)$ \\
\hline & South & 23 & 10 & 102.3 & $(3.6)$ & 127.5 & $(13.0)$ & 13.2 & (1.3) \\
\hline Ovalipes trimaculatus & Center & 16 & 28 & 79.4 & $(2.5)$ & 34.2 & $(3.3)$ & 5.1 & $(0.4)$ \\
\hline & South & 19 & 17 & 78.7 & $(1.3)$ & 32.8 & $(1.4)$ & 4.9 & $(0.2)$ \\
\hline Taliepus marginatus & Center & 29 & 5 & 42.2 & $(1.4)$ & 14 & $(1.5)$ & 1.1 & $(0.1)$ \\
\hline & South & 11 & 7 & 64.1 & $(1.0)$ & 50 & $(3.2)$ & 4.2 & $(0.2)$ \\
\hline
\end{tabular}

estimation in any of the five reproductive variables owing to embryo loss (Kuris 1991) or embryo growth, only females carrying early stage embryos were used to calculate brood weight ( $\mathrm{g}$, measured as dry weight of embryo mass), fecundity, embryo dry weight (g), and embryo volume $\left(\mathrm{mm}^{3}\right)$. The morphometric relationships between log-carapace wide $(\mathrm{cm}$, $\mathrm{CW}$ ) and log-female dry weight (g, FDW) was established for each species from each region using linear regressions.

\section{Brood weight}

Brood dry weight (g, BDW) and of the brooding females (after removing the embryos) were recorded for each female in the studied regions. All samples were oven-dried for $24 \mathrm{~h}$ at $100{ }^{\circ} \mathrm{C}$. We performed ANCOVAs separately for each species to compare mean BDW between regions, using FDW as covariate. Log transformation was used for both variables. Parallelism test was run before ANCOVA. When this assumption was not met, a separate slope model was run. Homogeneity of variance was assessed using the Cochran test.

\section{Fecundity}

In order to estimate fecundity, three subsamples (up to $0.005 \mathrm{~g}$ ), randomly taken from the border of each embryo mass, were weighed and the number of embryos in those samples were counted under a stereomicroscope. Fecundity of each female was estimated by extrapolating the ratio between number of embryos and dry weight of the sample of the embryos to the total embryo mass. Separate ANCOVAs were performed for each species to compare mean fecundity between regions, using FDW as covariate. Log transformation was used for both variables. Parallelism test was run before ANCOVA. When this assumption was not met, a separate slope model was run. Cochran test was used to assess homogeneity of variance.

\section{Dry weight and volume of embryos}

Volume $\left(\mathrm{mm}^{3}\right)$ and dry weight $(\mathrm{mg})$ of early stage embryos were calculated from the subsamples of embryos used to estimate fecundity (see above). The longest and shortest diameter of 10 embryos were measured. Embryo volume was calculated for each embryo as the volume of a sphere and the mean of each subsample was estimated. All subsamples were oven-dried for $24 \mathrm{~h}$ at $100{ }^{\circ} \mathrm{C}$. Finally, mean embryo dry weight was calculated from the relationship between total weight and the number of embryos in the subsample. For C. setosus, embryo dry weight 
and embryo volume were compared among regions using a 1 way-ANOVA. A SNK test was conducted for a posteriori comparisons. Student t-tests were used to compare embryo dry weights between central and southern Chile for the other four species. For H. plana mean embryo volume was compared using Student $t$ tests (no transformation were needed). MannWhitney $U$-tests were performed to compare embryo volume for the other three species $(O$. trimaculatus, $P$. barbiger and $T$. marginatus).

\section{Embryo loss}

In order to calculate embryo loss throughout development, fecundity and dry weight of females carrying late stage embryos were calculated (see above). From the relationship between fecundity of females carrying early stage embryos and FDW (see above), the expected fecundity of any given FDW was estimated for all the females carrying late stage embryos. The percentage difference between fecundity of females carrying late stage embryos and expected fecundity of those females when carried early stage embryos (regression) was used to obtain an estimator of embryo loss. Since the relationship between fecundity (at early stage) and female body dry weight of $T$. marginatus from the southern region was not significant, no estimation of embryo loss could be calculated for this species. For $C$. setosus, embryo loss (\%) among regions were compared using a one wayANOVA. A SNK test was conducted for a posteriori comparisons. For the three other species, Student t-tests were used. Data were not transformed.

\section{RESULTS}

Mean CW varied considerably among species, from $42.2 \mathrm{~cm}$ in $T$. marginatus to $102.3 \mathrm{~cm}$ in H. plana (Table 1). Similarly, mean FDW showed more than one order of magnitude of difference between the lightest and heaviest species $(P$. barbiger $=8.9 \mathrm{~g}$ and $H$. plana $=$ $127.5 \mathrm{~g}$, Table 1). FDW was significantly correlated with $\mathrm{CW}$ in all species and regions (Table 2). Females from southern Chile were larger and exhibited a higher FDW than females from the other two regions, with the exception of $O$. trimaculatus.

\section{Brood weight}

A wide range of BDW was observed among species when only females carrying early stage embryos are considered (Table 1). Paraxanthus barbiger and $C$. setosus showed the lowest and the highest BDW values, respectively. The slope of the allometric relationship between BDW and FDW differed among regions in $C$. setosus (Fig. 2, Parallelism test: $\mathrm{F}_{2,88}=12.36$, $\mathrm{P}$ $<0.001$ ), thus a separate slope model was run for this species. Significant differences were detected among regions $\left(\mathrm{F}_{2,88}=8.76, \mathrm{P}<0.05\right)$. A posteriori tests showed that $\mathrm{BDW}$ was lower in the northern region than in the two other localities $(\mathrm{P}<0.05)$. No differences were detected between center and southern regions $(\mathrm{P}>0.05)$. Regarding the other four species, no significant differences in the slopes between regions were found (Parallelism test: $P$. barbiger: $\mathrm{F}_{1,40}=0.27, \mathrm{P}=0.27 ; H$. plana: $\mathrm{F}_{1,44}=0.47, \mathrm{P}=0.49 ;$ O. trimaculatus: $\mathrm{F}_{1,31}=$ $0.32, \mathrm{P}=0.57 ;$ T. marginatus: $\mathrm{F}_{1,36}=1.20, \mathrm{P}=$

TABLE 2

Results of regression analysis between log-carapace width (CW) and log-female dry weight (FDW) for the five species analyzed at each region (north, center and south). Females carrying early and late stage embryos were pooled together in the analysis. All regressions were significant $(\mathrm{P}<0.001)$

Resultados de las regresiones lineales entre log-ancho de caparazón (CW) y log-peso seco de la hembra (FDW) para las cinco especies analizadas en cada región (norte, centro y sur). Hembras con embriones en estado temprano y tardío fueron agrupadas. Todas las regresiones fueron significativas $(\mathrm{P}<0,001)$

\begin{tabular}{llcc}
\hline Species & North & Center & South \\
\hline Cancer setosus & $\log (\mathrm{FDW})=3.09(\log (\mathrm{CW}))-4.35$ & $\log (\mathrm{FDW})=2.77(\log (\mathrm{CW}))-3.74$ & $\log (\mathrm{FDW})=3.03(\log (\mathrm{CW}))-4.17$ \\
Paraxanthus barbiger & $\log (\mathrm{FDW})=2.59(\log (\mathrm{CW}))-3.34$ & $\log (\mathrm{FDW})=2.77(\log (\mathrm{CW}))-3.60$ \\
Homalaspis plana & $\log (\mathrm{FDW})=3.02(\log (\mathrm{CW}))-4.08$ & $\log (\mathrm{FDW})=2.92(\log (\mathrm{CW}))-3.80$ \\
Ovalipes trimaculatus & $\log (\mathrm{FDW})=2.93(\log (\mathrm{CW}))-4.06$ & $\log (\mathrm{FDW})=1.94(\log (\mathrm{CW}))-2.17$ \\
Taliepus marginatus & $\log (\mathrm{FDW})=2.53(\log (\mathrm{CW}))-3.00$ & $\log (\mathrm{FDW})=3.68(\log (\mathrm{CW}))-5.00$ \\
\hline
\end{tabular}



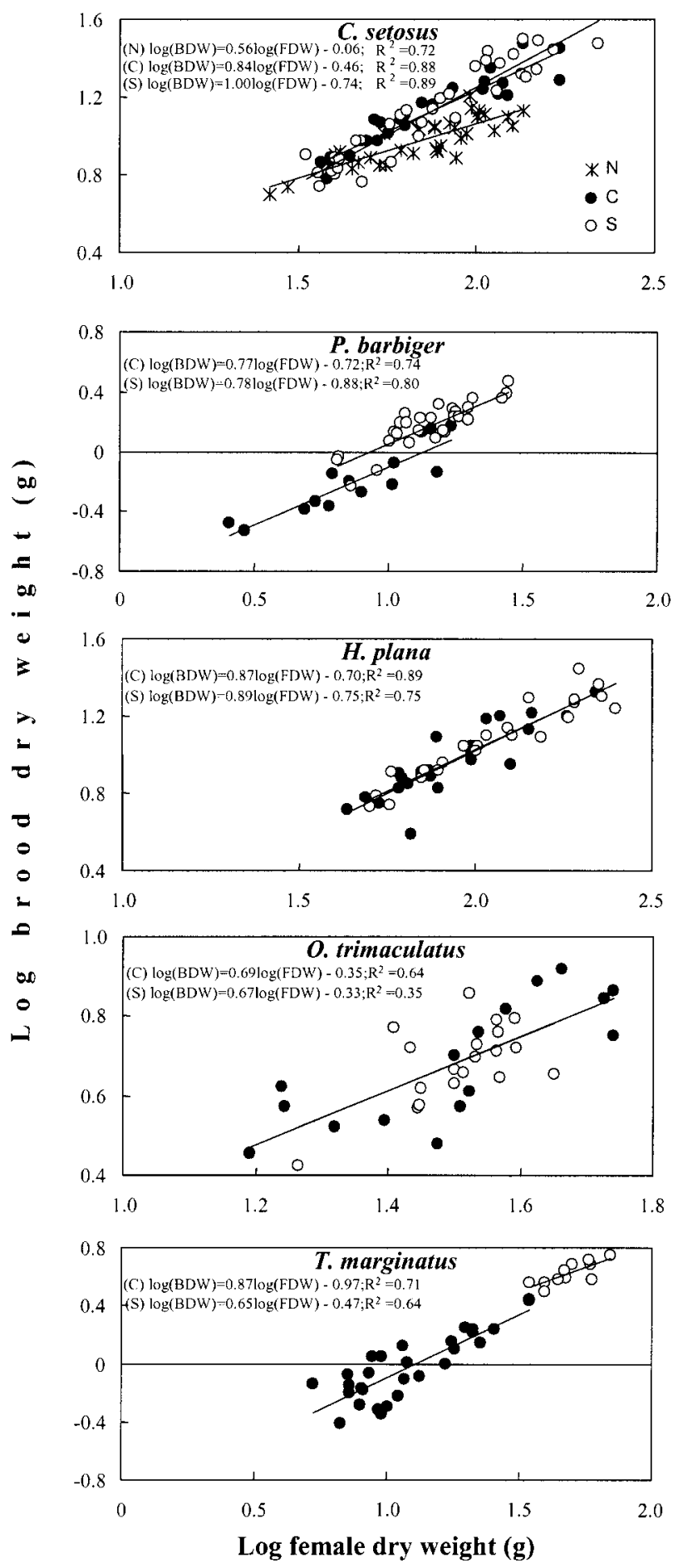

Fig. 2: Relationship between log-female dry weight (FDW) and log-brood dry weight (BDW) for five Brachyuran species in three regions along the Chilean coast. Data were obtained from female crabs carrying embryos at early stage. The regression equations and the coefficient of determinations $\left(\mathrm{R}^{2}\right)$ are also shown for northern $(\mathrm{N})$, central $(\mathrm{C})$ and southern $(\mathrm{S})$ Chile. All regressions were significant $(\mathrm{P}<0.05)$.

Relación entre log-peso seco de la hembra (FDW) y log-peso seco de la masa de embriones (BDW) para cinco especies de braquiuros en tres regiones a lo largo de la costa de Chile. Los datos fueron obtenidos de hembras con embriones en estado temprano. Las ecuaciones de regresión y los coeficientes de determinación $\left(\mathrm{R}^{2}\right)$ son mostradas para la región norte $(\mathrm{N})$, centro $(\mathrm{C})$ y sur $(\mathrm{S})$. Todas las regresiones fueron significativas $(\mathrm{P}<0,05)$. 
0.28), and slopes were always below 1 (Fig. 2). BDW did not differ statistically between regions in $H$. plana, O. trimaculatus, and $T$. marginatus after removing the influence of female size (Table 3). A significant increase in BDW from the center to the south was detected in $P$. barbiger (Table 3 ).

\section{Fecundity}

The mean number of embryos per brood ranged from 31,407 in $P$. barbiger to $1,381,867$ in $C$. setosus. Fecundity was positively correlated with FDW for all species and regions (always P $<0.05$; Fig. 3). All slopes from allometric

TABLE 3

Summary of ANOVAs and Student t-tests performed for each species to compare brood dry weight, fecundity, embryo dry weight, embryo volume and embryo losses during incubation among regions (north, center and south). Only female crabs carrying embryos at early stage were used in all cases except for embryo losses. (nd) = no data available for comparisons; (*) the Z-value is reported

Resumen de los ANDEVAs y pruebas t de Student realizados para cada especie para comparar entre regiones (norte, centro y sur): peso seco de la masa de huevos, fecundidad, peso seco del embrión, volumen del embrión y pérdida de embriones durante la incubación. Exceptuando la pérdida de huevos, en todos los casos fueron usadas solamente hembras con embriones tempranos. $(\mathrm{nd})=$ no hay datos disponibles para las comparaciones; (*) se reporta el valor de $\mathrm{Z}$

\begin{tabular}{|c|c|c|c|}
\hline Variable and species & Degrees of freedom & F-value (t-value)* & P-value \\
\hline \multicolumn{4}{|l|}{ Brood dry weight } \\
\hline Paraxanthus barbiger & 1,41 & 22.0 & $<0.001$ \\
\hline Homalaspis plana & 1,44 & 0.15 & 0.7 \\
\hline Ovalipes trimaculatus & 1,32 & 0.01 & 0.91 \\
\hline Taliepus marginatus & 1,37 & 2.21 & 0.14 \\
\hline \multicolumn{4}{|l|}{ Fecundity } \\
\hline Paraxanthus barbiger & 1,41 & 2.11 & 0.15 \\
\hline Homalaspis plana & 1,44 & 0.01 & 0.92 \\
\hline Ovalipes trimaculatus & 1,32 & 9.08 & 0.005 \\
\hline Taliepus marginatus & 1,37 & 2.21 & 0.14 \\
\hline \multicolumn{4}{|l|}{ Embryo dry weight } \\
\hline Cancer setosus & 2,82 & 24.36 & $<0.001$ \\
\hline Paraxanthus barbiger & 42 & $(-2.57)$ & 0.02 \\
\hline Homalaspis plana & 46 & $(0.96)$ & 0.34 \\
\hline Ovalipes trimaculatus & 33 & $(-3.51)$ & $<0.01$ \\
\hline Taliepus marginatus & 38 & $(-11.41)$ & $<0.001$ \\
\hline \multicolumn{4}{|l|}{ Embryo volume } \\
\hline Cancer setosus & 2,82 & 17.24 & $<0.01$ \\
\hline Homalaspis plana & 36 & $(0.86)$ & 0.40 \\
\hline Paraxanthus barbiger & 57 & $(-3.35)^{*}$ & $<0.001$ \\
\hline Ovalipes trimaculatus & 28 & $(-3.9)^{*}$ & $<0.001$ \\
\hline Taliepus marginatus & 24 & $(-3.87)^{*}$ & $<0.001$ \\
\hline \multicolumn{4}{|l|}{ Embryo loss } \\
\hline Cancer setosus & 2,86 & 5.55 & $<0.005$ \\
\hline Paraxanthus barbiger & 13 & $(0.7)$ & 0.5 \\
\hline Homalaspis plana & 36 & $(1.52)$ & 0.14 \\
\hline Ovalipes trimaculatus & 41 & $(3.34)$ & 0.002 \\
\hline Taliepus marginatus & nd & & \\
\hline
\end{tabular}



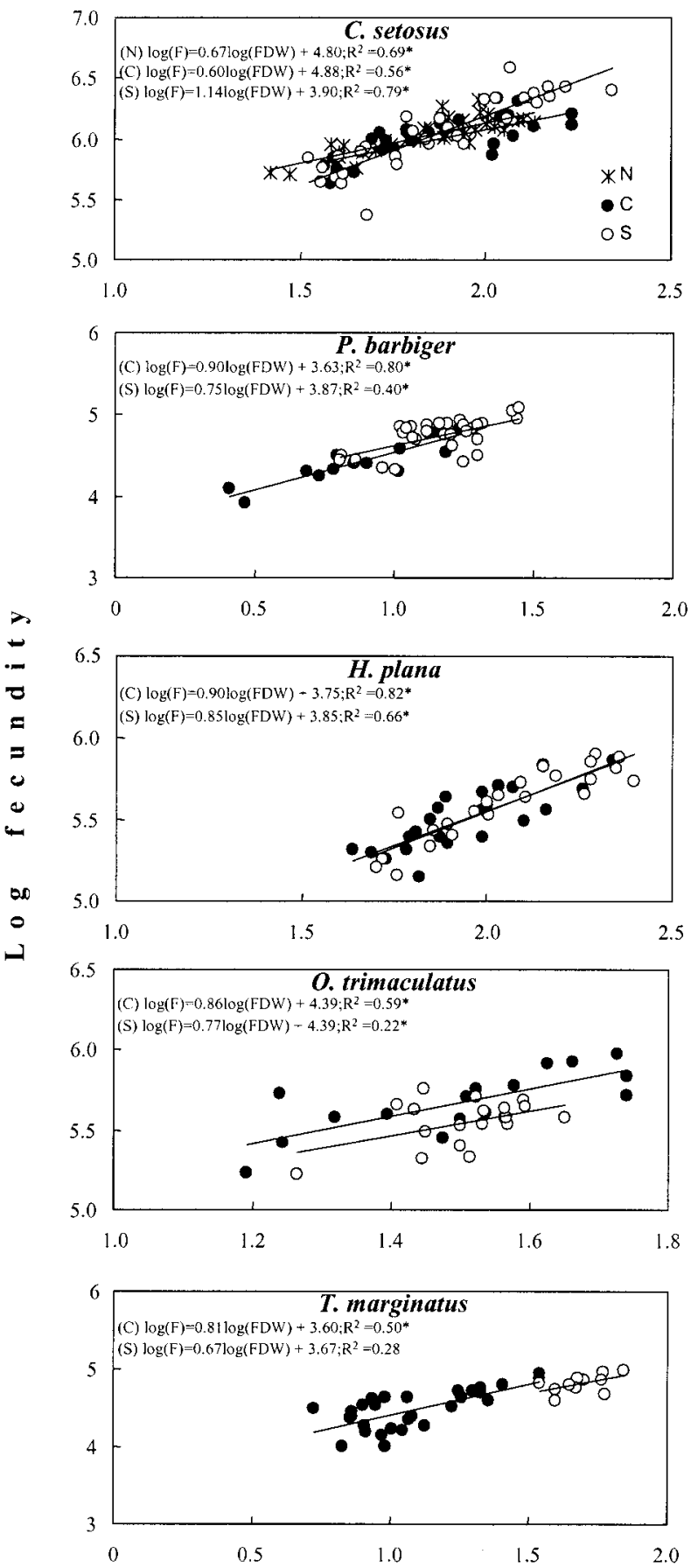

Log female dry weight $(\mathrm{g})$

Fig. 3: Relationship between log-female dry weight (FDW) and log-fecundity (F) for five Brachyuran species in three regions along the Chilean coast. Data were obtained from female crabs carrying embryos at early stage. The regression equations and the coefficient of determinations $\left(\mathrm{R}^{2}\right)$ are shown for northern (N), central (C) and southern (S) Chile. Asterisks indicate significant relationship between variables $(\mathrm{P}<0.05)$.

Relación entre log-peso seco de la hembra (FDW) y log-fecundidad (F) para cinco especies de braquiuros en tres regiones a lo largo de la costa de Chile. Los datos fueron obtenidos de hembras con embriones en estado temprano. Las ecuaciones de regresión y los coeficientes de determinación $\left(\mathrm{R}^{2}\right)$ son mostradas para la región norte $(\mathrm{N})$, centro (C) y sur (S). Los asteriscos indican relaciones significativas entre variables $(\mathrm{P}<0,05)$. 
relationships, except for $C$. setosus from southern Chile, were $<1$ (Fig. 3). Regression slopes differed among regions for $C$. setosus (parallelism test: $\mathrm{F}_{2,88}=9.91, \mathrm{P}<0.001$ ), therefore a separate slope model was run for this species. Significant differences were detected among regions $\left(\mathrm{F}_{2,88}=9.359, \mathrm{P}<\right.$ $0.05)$. Although no differences could be detected after using a posteriori tests $(\mathrm{P}>$ 0.05), the slope of the relationship FDW and fecundity in the north seemed to be differ from the other two regions. Fecundity of $H$. plana, $P$. barbiger and $T$. marginatus did not show significant differences between regions after female size was controlled for (Table 3 ).
Fecundity of $O$. trimaculatus was higher in central than in southern Chile (Table 3).

\section{Dry weight and volume of embryos}

Mean embryo dry weight ranged between 0.009 to $0.066 \mathrm{mg}$ for $C$. setosus and T. marginatus, respectively (Fig. 4A). Mean embryo dry weight was significantly lower in central than in southern Chile for $P$. barbiger, $O$. trimaculatus and T. marginatus (Table 3 ). The other two species did not exhibit significant differences between these two regions (Table 3 ). However, mean embryo dry weight of $C$. setosus in northern Chile was significantly
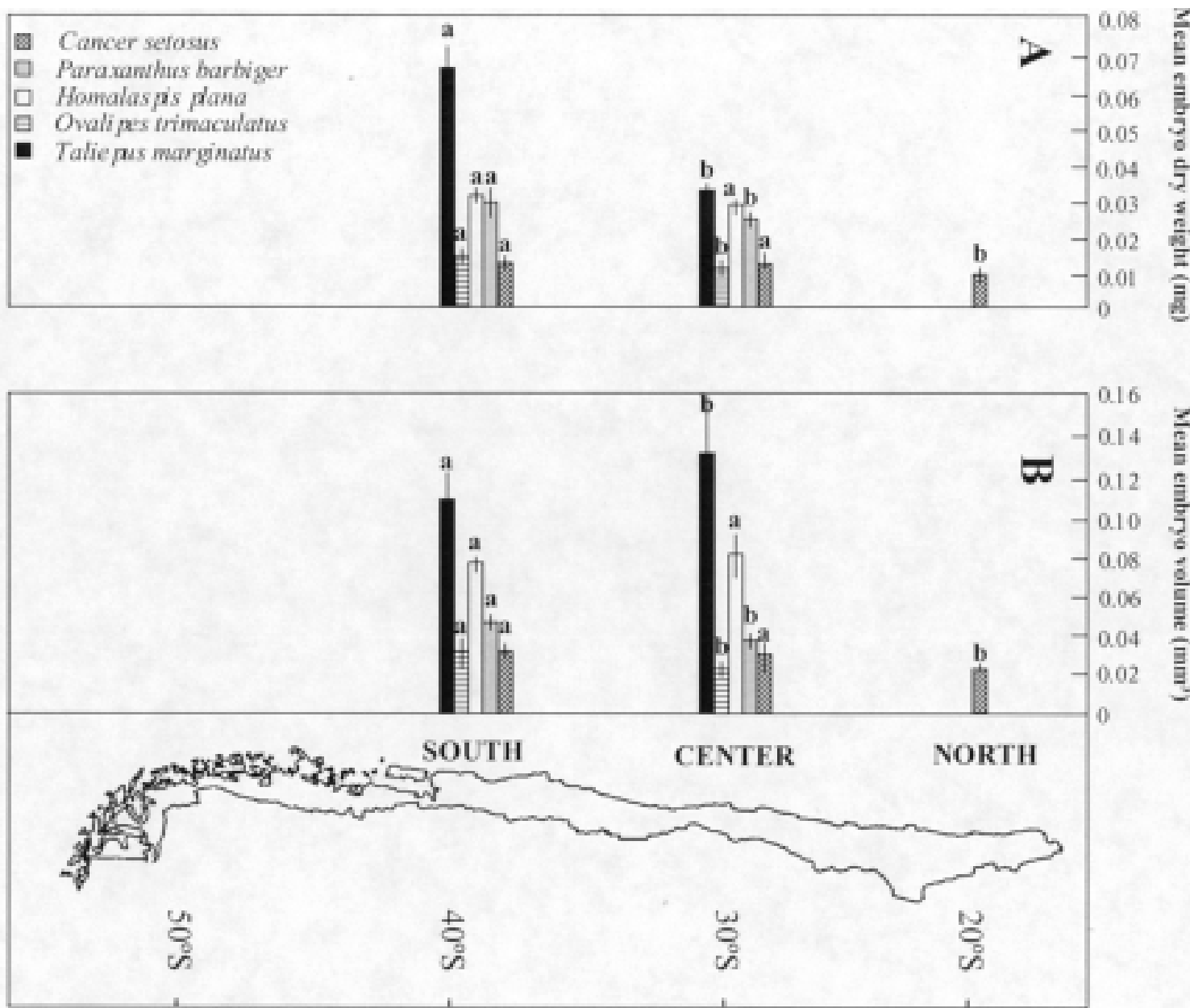

Fig. 4: Latitudinal comparisons of (a) mean embryo dry weight (mg) and (b) mean embryo volume $\left(\mathrm{mm}^{3}\right)$ of five Brachyuran species in the three study regions along the Chilean coast. Solid lines indicate 1 standard error. Equal symbols above the bars indicate no significant differences among regions within species.

Comparaciones latitudinales de (a) peso seco promedio del embrión $(\mathrm{mg})$ y (b) volumen promedio del embrión $\left(\mathrm{mm}^{3}\right)$ en cinco especies de braquiuros en las tres regiones estudiadas a lo largo de la costa de Chile. Las líneas continuas indican 1 error estándar. Símbolos iguales sobre las barras indican diferencias intraespecíficas no significativas entre regiones. 
lower than in the other two regions (Table 3). Mean embryo volume ranged between 0.021 and $0.126 \mathrm{~mm}^{3}$ in $O$. trimaculatus and $T$. marginatus, respectively (Fig. 4B). In $P$. barbiger and $O$. trimaculatus, embryo volume significantly increased from central to southern Chile (Table 3). In contrast, T. marginatus showed the opposite tendency (volume decreased toward the south). No significant differences between central and southern Chile were detected in $H$. plana and $C$. setosus (Tabla 3 ). However mean volume of embryos was significantly lower in northern Chile for $C$. setosus (Table 3 ).

\section{Embryo loss}

The percentage of embryo loss throughout development varied between $3.6 \%$ for $C$. setosus and $56.7 \%$ for O. trimaculatus, respectively (Fig. 5). Only $C$. setosus and $O$. trimaculatus showed significance differences in the percentage of embryo losses among regions (Table 3). A higher percentage of embryo loss was found for $C$. setosus in northern Chile than in the other two regions, but no significant differences were detected between central and southern Chile. Similarly, a significant increase in the mean percentage of embryo loss towards lower latitudes was detected in $O$. trimaculatus.

\section{DISCUSSION}

Although we did not find a clear and consistent pattern in all reproductive variables in the five crab species analyzed along the coast of Chile, some generalizations can be drawn from this study. First, brood weight did not vary between central and southern Chile in four of the five species (the only exception being $P$. barbiger). Second, embryo losses did not vary between central and southern Chile in four of the five species studied. Third, embryo dry weight tended to increase toward high latitudes in four species. Some species (H. plana, C. setosus) showed a clear and consistent pattern in all reproductive variables among regions, while different patterns between regions were observed in other species ( $P$. barbiger, $O$.

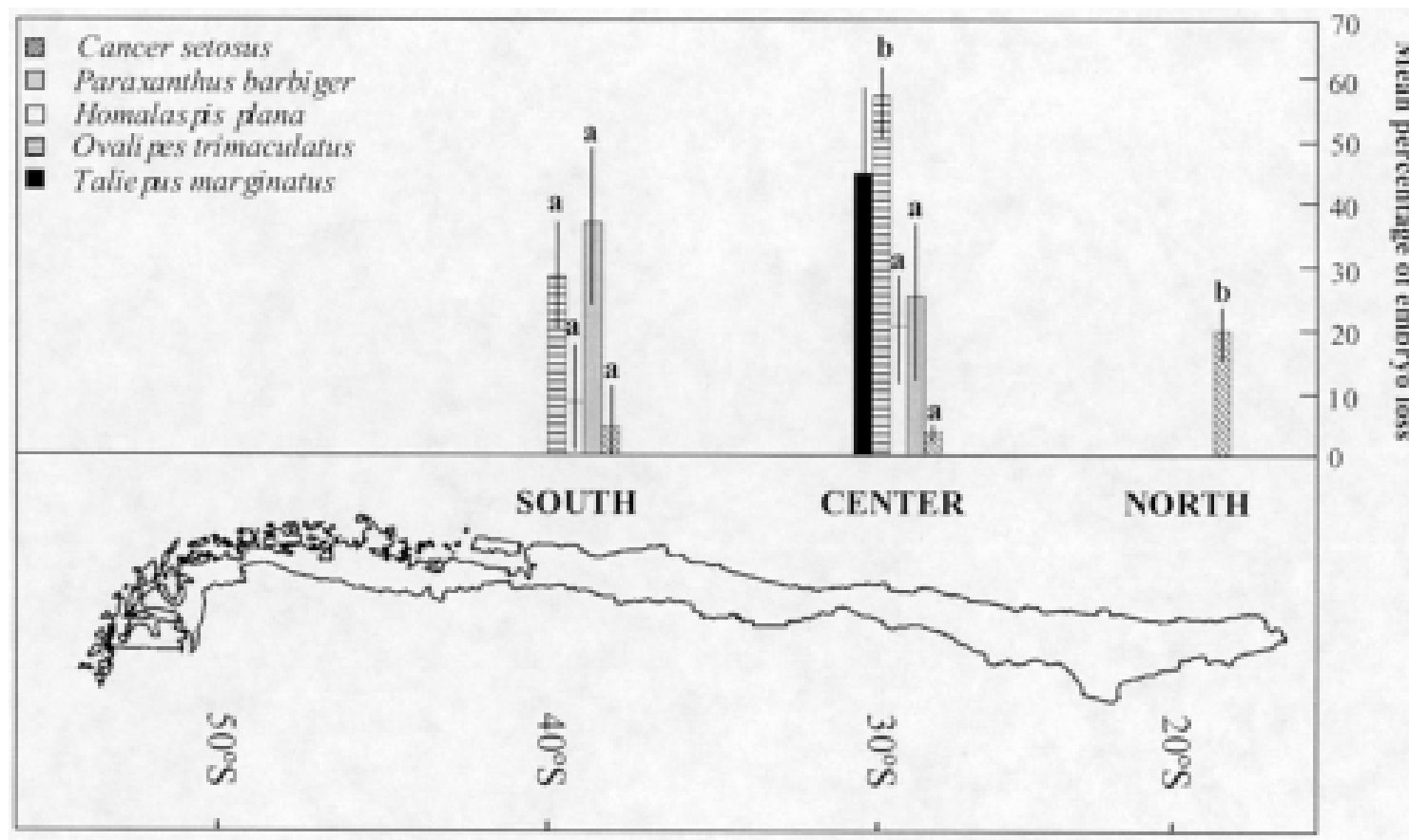

Fig. 5: Latitudinal comparisons of the mean percentage of embryo loss during incubation time of five Brachyuran species in the three study regions along the Chilean coast. Solid lines indicate 1 standard error. Equal symbols above the bars indicate no significant differences among regions within species.

Comparaciones latitudinales de la pérdida de embriones promedio durante el tiempo de incubación en cinco especies de braquiuros en las tres regiones estudiadas a lo largo de la costa de Chile. Las líneas continuas indican 1 error estándar. Símbolos iguales sobre las barras indican diferencias intraespecíficas no significativas entre regiones. 
trimaculatus, T. marginatus). Here, we present the first report of $T$. marginatus inhabiting localities south of Talcahuano $\left(36^{\circ} \mathrm{S}\right)$.

The most dramatic differences in most reproductive variables occurred between the north and the rest of the areas sampled. Females of $C$. setosus (the only species found brooding in northern Chile) from northern Chile exhibited lower brood weights than females from central and southern Chile. Embryo size, embryo volume, and embryo loss also showed differences between the north, and the rest of the coast. Larger embryos at high latitudes (i.e., where conditions of low temperatures prevail) can be explained by high amounts of yolk, a pattern well known among Brachyuran crabs (Wear 1974). However, smaller and lighter embryos at lower latitudes may also reflect local adaptation to higher mean temperatures (Brante et al. 2003). This interpretation is in line with a general trend observed among marine invertebrates in that relatively cold water temperatures result in large-sized organisms compared with warm water species, because cold waters usually have higher levels of dissolved oxygen (Chapelle \& Peck 1999 for amphipods; Pörtner 2002 for cephalopods). This trend may extend to embryo size, which would also benefit from elevated oxygen solubility given the strong oxygen limitation observed in embryo masses during early development (Fernández et al. 2000, Fernández et al. 2002). In fact, the high rate of embryo loss and the low BDW at lower latitudes might be associated to a need for the parents to provide oxygen to the embryos. A higher cost of ventilation at higher temperatures (lower latitudes) seems to affect investment in eggs, decreasing reproductive output (Brante et al. 2003). High embryo loss can also be the result of a high ventilation frequency at high temperatures, which may result from mechanical losses (Kuris et al. 1991, Brante et al. 2003).

Patterns of BDW and fecundity between central and southern Chile were consistent in most of species included in this study. Cancer setosus, H. plana, O. Trimaculatus, and T. marginatus did not show any difference in BDW and fecundity between central and southern Chile. The only species that showed differences in BDW between these two regions was $P$. barbiger, although its fecundity did not change. A similar finding has been reported for Pinnaxodes chilensis (Lardies \& Castilla 2001). Thus, these two reproductive variables seem to be little affected by variations in temperature or other environmental variables that might have been expected to affect energy available for reproduction, such as productivity, between 29 and $41^{\circ} \mathrm{S}$. An average $18 \%$ decrease in average sea surface temperature and a $28 \%$ increase in chlorophyl- $a$ has been reported between central and southern Chile (Thomas 1999). Low temperature conditions, which may lower the cost of brooding (Brante et al. 2003) and higher food availability seemed not to result in higher energy input in eggs. This finding is in line of Hines' (1982) hypothesis, according to which an allometric limitation of available space for yolk accumulation in the body cavity is a major constraint on brood size. The issues of how the brooding cost varies with temperature, how the cost of embryo ventilation affects egg production, and if such trade-off, found in $C$. setosus (see Brante et al. 2003), also occurs in other crab species remains unclear.

Cancer setosus from southern Chile exhibited a different relationship between FDW and BDW, and between FDW and fecundity, than the rest of the species and regions. The slopes of both regressions for all species and regions (except $C$. setosus from southern Chile) were always $<1$, indicating that larger crabs have proportionally smaller broods (and lower fecundity) than smaller crabs. Although females of $C$. setosus from central and northern Chile also showed such a relationship, slopes were larger than unity in southern Chile, suggesting that larger females are able to produce more eggs than similarly sized females in lower latitudes (i.e., higher temperatures). The effect of body size on egg production needs further exploration, but a constraint on egg production should be expected for large sized individuals given the cost of oxygen provision to the egg mass (Fernández et al. 2000). The trade-off between egg production and investment in oxygen provision to embryos (Brante et al. 2003) supports this hypothesis. It is important to remark that female size tended to be larger in southern Chile for most of the species. Large brood size, expected in larger females, is more feasible in cold waters (high latitudes) if the costs association to oxygen provision to the brood is an important selective force. Large-sized organisms in cold waters, where dissolved oxygen increases, has also been reported for other groups of marine invertebrates (Chapelle \& Peck 1999 for amphipods; Pörtner 2002 for cephalopods).

Embryo loss varied enormously among species and regions, reaching $56.7 \%$ in $O$. trimaculatus in central Chile. This range is similar to those reported for other Brachyuran crabs (Kuris 1991, Fernández et al. 2000, 
Lardies \& Castilla 2001). Moreover, the higher rate of embryo loss in $O$. trimaculatus coincides well with those reported for other species of the Portunidae family (Kuris 1991), suggesting that losses are substantially higher within this family (above $50 \%$ ). Embryo loss has been hypothesized to result from (1) a limitation of space under the cephalotorax to carry the embryos (Corey \& Reid 1991, Hines 1982), and (2) from an accidental action during the mechanical process of brood ventilation (Kuris 1991, Fernández et al. 2000). A direct relationship between embryo ventilation and percentage of embryo loss has been reported for Cancer pagurus, C. setosus, and Maja squinado (Fernández et al. 2000, Brante et al. 2003). We found a higher rate of embryo loss in $C$. setosus at low latitudes, and in $O$. trimaculatus in general, but toward lower latitudes in particular. As shown by Brante et al. (2003), the high rates of embryo losses in $C$. setosus are caused by a higher ventilation frequency at high temperatures (low latitudes). A high ventilation frequency also may be responsible for the relatively high rate of embryo loss found in O. trimaculatus between central and southern Chile; this species shows levels of activity that are higher than the other species, which makes it more sensitive to changes in temperature. However, we did not test this hypothesis directly and therefore, alternative explanations can be proposed. For instance, differential rates of parasitism and disease infection, which may also be correlated with ambient temperature, could affect embryo loss through a latitudinal (temperature) gradient. High rates of embryo loss suggest the need to consider this factor in future studies of fecundity or reproductive output, by means of using females carrying early stage embryos to estimate both variables.

Latitudinal patterns observed in brood dry weight can be explained by the combined effects of fecundity and embryo dry weight. With the exception of $T$. marginatus, embryo dry weight showed the same latitudinal pattern as did embryo volume. In general, we found that both embryo dry weight and volume increased with latitude. This is a common trend among marine invertebrates (Barnes \& Barnes 1965, Efford 1969, Lardies \& Castilla 2001, Brante et al. 2003), but controversial among crustaceans (Diaz 1980, Wooward \& White 1981, Jones \& Simons 1983). Our data strongly support the trend reported for marine invertebrates, since embryo volume consistently increased toward the south. Although low salinity in the southern region might explain the increase of embryo volume of Pinnaxodes chilensis (Lardies \& Castilla 2001), the simultaneous increase of embryo volume and dry weight in most species supports the hypothesis that yolk accumulation rather than environmental variables explain patterns of embryo volume.

It is interesting that $P$. barbiger and $O$. trimaculatus showed differences between central and southern Chile for more variables than any of the other species (brood weight, embryo dry weight, and embryo volume in P. barbiger and fecundity, embryo dry weight, embryo volume and embryo losses in $O$. trimaculatus). Both species show their southern end of distribution in our southern study region. This finding suggests that reproductive variables show differences along the distribution of the species, particularly towards the distribution limits, but more studies are needed along this line to explore this hypothesis.

\section{ACKNOWLEDGEMENTS}

We are grateful to Iván Albornoz, Antonio Baeza, Fernando Ogalde and Nathaly Ruiz-Tagle for their help. We also thank Luis Ebensperger, Martin Thiel, and one anonymous reviewer for their helpful comments. This study was supported by the FONDAP \#3 (Crustaceans), the Volkswagen Foundation, the Humboldt Foundation, FONDECYT 1020860, and FONDAPFONDECYT (Grant 1501-0001). We also thank the Deutscher Akademischer Austauschdienst (DAAD). A. B. acknowledges financial support from CONICYT (doctoral fellowship).

\section{LITERATURE CITED}

BAEZA JA \& M FERNÁNDEZ (2002) Active brood care in Cancer setosus (Crustacea: Decapoda): the relationship between female behaviour, embryo oxygen consumption, and the cost of brooding. Functional Ecology 16: 241-251.

BARNES H \& M BARNES (1965) Egg numbers, metabolic efficiency of egg production and fecundity; local and regional variations in a number of common cirripeds. Journal of Experimental Marine Biology and Ecology 2: 135-153.

BOSCHI (2000) Biodiversity of marine decapod brachyurans of the Americas. Journal of Crustacean Biology 2: 337-342.

BRANTE A, M FERNÁNDEZ, L ECKERLE, F MARK, H-O PÖRTNER \& W ARNTZ (2003) Reproductive investment in the crab, Cancer setosus, along a latitudinal cline: egg production, egg losses and egg ventilation. Marine Ecology Progress Series 251: 221-232. 
BREY T (1995) Temperature and reproductive metabolism in macrobentic populations. Marine Ecology Progress Series 125, 87-93.

CARVACHO A, R TAPIA \& C VIDAL (1995) Aspectos reproductivos de la jaiba mora, Homalaspis plana (Milne-Edwards 1834) (Crustacea: Brachyura: Xanthidae) en el seno de Reloncaví, Chile. Biología Pesquera (Chile) 24: 7-15.

CHAPELLE G \& LS PECK (1999) Polar gigantism dictated by oxygen availability? Nature 399: 114-115.

CLARKE A (1987) Temperature, latitude and reproductive effort. Marine Ecology Progress Series 38: 89-99.

COHEN C \& R STRATHMANN (1996) Embryos at the edge of tolerance: effects of environment and structure of embryo masses on supply of oxygen to embryos. Biological Bulletin 190: 8-15.

COREY S \& DM REID (1991) Comparative fecundity of Decapod crustaceans. I. The fecundity of thirtythree species of nine families of Caridean shrimp. Crustaceana 60: 270-294.

DÍAZ H (1980) The mole crab Emerita talpoida (Say): a case of changing life history pattern. Ecological Monographs 50: 437-456.

EFFORD IE (1969) Recruitment to sedentary marine populations as exemplified by the sand crab, Emerita analoga (Decapoda, Hippidae). Crustaceana 18: 293-308.

FARIÑA AC, J FREIRE \& E GONZÁLEZ-GURRIARÁN (1999) Fecundity of the Norway lobster Nephrops norvegicus in Galicia (NW Spain) and a review of geographical patterns. Ophelia 50: 177-189.

FERNÁNDEZ M, C BOCK \& H PÖRTNER (2000) The cost of being a caring mother: the ignored factor in the reproduction of marine invertebrates. Ecology Letters 3: 487-494.

FERNÁNDEZ M., LM PARDO \& A BAEZA (2002) Patterns of oxygen supply in embryo masses of Brachyuran crabs throughout development: the effect of oxygen availability and chemical clues in determining female behavior. Marine Ecology Progress Series 245: 181-190.

GALLARDO C \& P PENCHASZADEH (2001) Hatching mode and latitude in marine gastropods: revisiting Thorson's paradigm in the southern hemisphere. Marine Biology 138: 547-552.

GIRALDO A, R ESCRIBANO \& V MARIN (2002) Spatial distribution of Calanus chilensis off Mejillones Peninsula (northern Chile): ecological consequences upon coastal upwelling. Marine Ecology Progress Series 230: 225-234.
HINES AH (1982) Allometric constraints and variables of reproductive effort in Brachyuran crabs. Marine Biology 69: 309-320.

JONES MB \& MJ SIMONS (1983) Latitudinal variation in reproductive characteristics of a mud crab, Helice crassa. Bulletin of Marine Science 33: 656-670.

KURIS (1991) A review of patterns and causes of crustacean brood mortality. In: Schram FR (ed) Crustacean issues, Volume 7: 117-141. Balkema, Rotterdam, The Netherlands.

LARDIES M \& JC CASTILLA (2001) Latitudinal variation in the reproductive biology of the commensal crab Pinnaxodes chilensis (Decapoda: Pinnotheridae) along the Chilean coast. Marine Biology 139: 1125-1133.

PÖRTNER H-O (2002) Environmental and functional limits to muscular exercise and body size in marine invertebrate athletes. Comparative Biochemistry and Physiology Part A 133: 303-321.

SERVICIO HIDROGRÁFICO Y OCEANOGRÁFICO DE LA ARMADA DE CHILE (1996) Atlas oceanográfico de Chile. Volumen 1. Servicio Hidrográfico y oceanográfico de la Armada de Chile, Valparaíso, Chile.

SPIGHT TM (1977) Latitude, habitat and hatching type for Muricean gastropods. Nautilus 91: 67-71.

STRATHMANN R \& M STRATHMANN (1982) The relation between adult size and brooding in marine invertebrates. American Naturalist 119: 91-101.

STRUB PT, JM MESÍAS, $\mathrm{V}$ MONTECINO, J RUTLLANT AND S SALINAS (1998) Coastal ocean circulation off western South America. The Sea 11: 273-313.

THOMAS AC (1999) Seasonal distribution of satellitemeasured phyoplankton pigment concentration along the Chilean coast. Journal of Geophysical Research 104: 25877-25890.

THORSON G (1950) Reproduction and larval ecology of marine bottom invertebrates. Biological Review 25: $1-45$.

WEAR RG (1974) Incubation in British Decapod Crustacea, and the effects of temperature on the rate and success of embryonic development. Journal of the Marine Biological Association of the United of Kingdom 54: 745-762.

WOOWARD IO \& RWG WHITE (1981) Effects of temperature and food on the fecundity and egg development rates of Boeckella symmetrica Sars (Copepoda: Calanoidea). Australian Journal of Marine and Freshwater Research 32: 997-1002. 